\title{
Home Production of Milk and Dairy Products
}

\author{
By H. D. KaY, National Institute for Research in Dairying, \\ University of Reading
}

Milk

As regards milk, I have made some calculations from Tables 3 and 4 of the paper of Dr Magee and his collaborators (Bransby, Magee, Bowley \& Stanton, 1947). What in effect is asked for, in that paper, is the provision, in 1946 , for liquid consumption of almost $1700 \times 10^{6} \mathrm{gal}$. of milk, or $0.774 \mathrm{pt}$./head/day on the average, and, in 1964 , of some $1720 \times 10^{6}$ gal. or about $0.75 \mathrm{pt}$./head/day.

In Table $\mathrm{I}$ the actual liquid milk consumption in the United Kingdom for the year I945-6 is given from official data provided by Milk Marketing Boards or Ministries.

Table I. Liquid milk consumption and manufacture in the United Kingdom for the year 1945-6 (Scotland and Northern Ireland figures are for 1944-5)

$\begin{array}{lcrrr} & \begin{array}{c}\left.\text { (gal. } \times 10^{6} .\right) \\ \text { England and }\end{array} & & & \\ & \text { Wales } & \text { Scotland } & \text { N. Ireland } & \text { Total } \\ \text { Total sold off farms } & 1260 & 156 & 70 & 1486 \\ \text { Manufactured } & 127 & 20 & 25 & 172 \\ \text { Sold for liquid consumption } & 1133 & 136 & 45 & 1314 \\ \text { Add 3\% (of total sold off farms) for } & 38 & 5 & 2 & 45 \\ \quad \text { farm (human) consumption } & & & & \\ \quad \text { Total consumed liquid } & 1171 & 141 & 47 & 1359\end{array}$

The daily liquid milk consumption, therefore, is at present $0.62 \mathrm{pt}$./ head on the average; this figure has to be raised as soon as possible to 0.77 pt., i.e. an increase over $1945^{-6}$ of rather more than $24 \%$ in liquid milk consumption/head.

All the vast quantity of liquid milk at present consumed in the United Kingdom, and presumably the still larger quantities of milk needed to satisfy the nutritional requirements as outlined by Bransby et al., have to be produced in the United Kingdom. The dimensions of the liquid milk problem from the dairy farmers' standpoint (or rather from the agricultural standpoint, since farming in the large majority of holdings in these islands is an integrated whole and cannot be divided into milk-tight compartments) will, therefore, be to provide an increase of, to give a round figure, $25 \%$ in milk coming off farms. This means, virtually, an increase of $25 \%$ in total production. The assumption is made that the small quantity of milk now going to manufacture will remain unchanged, though, in fact, with increasing home milk-production and increasing difficulties of buying dairy products abroad, it might increase. It also means the assumption that the small amount of milk used on the farm for calf rearing-which may be taken at, perhaps, $3 \%$ of the total milk produced-will remain sensibly unchanged.

In the Ministry of Agriculture's expansion programme recently published (Ministry of Agriculture and Fisheries, 1947), the following increase in milk production is 
envisaged. Pre-war production is taken as I00, 1943-4 was about I01, 1946-7 about 107 , and the figure to be attained in $1955^{1-2}$ (i.e. in under 5 years from now) is 123 . The Ministry's target for $195 \mathrm{I}-2$ is thus about $15 \%$ above the production of $1945^{-6}$. The nutritional demands of Dr Magee and his collaborators on the same basis of calculation entail a production target of $13 \mathrm{r}$.

The rise of $15 \%$ in milk production called for by the Ministry's programme has to take place simultaneously with a rise in egg production of over $90 \%$ above $1946-7$, a rise in beef and veal production of some $18 \%$, a rise in mutton and lamb of $10 \%$ and a rise in pig meat of $170 \%$, accompanied by an increase in wheat production of $33 \%$ and a small increase in barley and in oats-all by $195 \mathrm{I}-2$. The only decrease is a fall in potatoes to $60 \%$ of the $1946-7$ figure. Clearly, without a very great improvement in agricultural efficiency-production/acre and production/man-these targets cannot be reached. The fulfilment of Dr Magee's nutritional programme, entailing an even larger increase in liquid milk production- $25 \%$ as against $15 \%$-will be handicapped similarly by the simultaneous need to meet other food-production requirements from the limited home acreage. This acreage cannot be significantly increased in area by taking in marginal land or by reclamation. Nevertheless, there is still some good farming land to be liberated from wartime uses.

How far and how quickly can either the Ministry of Agriculture's or Dr Magee's milk programme be fulfilled?

The cow, essentially a herbivore, is, in the main, a consumer of relatively coarse fodders unsuited for human food, and to a large extent unsuited for pigs and poultry. Nevertheless, if she is to give a satisfactory yield of milk, particularly in the winter, she must, of course, receive, in addition to a maintenance ration which may consist largely of grass, hay and coarse farm fodders, a considerable quantity, varying with her milk yield, of concentrates fairly rich in protein. Typical concentrate mixtures for milk production by high-yielding cows-and they are necessary for such animals for the greater part of the year-consist of grain and oilcake, or of beanmeal, grain and oilcake. The higher the milk production, the greater care must be taken in improving the digestible-energy content of the cow's diet, or her yield will fall off. During lactation, though her need for energy and protein may be greatly increased, her capacity for dealing with bulk in her foodstuff remains strictly limited.

As is well known, during the war our imports from abroad of oilcake and grain for livestock feeding diminished greatly, and they have, unfortunately, increased only slightly since the war. They reached their lowest level, 19\% of pre-war, in 1943. In 1945 , they were $29 \%$ of pre-war, and again $29 \%$ in 1946 . In 1947 , so far, the changes from 1946 have been insignificant. Imported concentrates have been replaced, in part only, by home-produced semi-concentrates such as silage prepared from young grass or from cereal and legume mixtures cut young; we have endeavoured to produce better-quality hay with a higher energy (starch equivalent) and protein content by earlier cutting and by improving our strains of grasses. Some farmers have grown more beans, others more linseed. The grazing period has, on some farms, been extended by the use of special grass mixtures, by the skilled use of what fertilizers were available and by grassland management. 
Despite these and similar endeavours, carried out under the tremendous urge of war, assisted by the drive of the County War Agricultural Executive Committees, and without the simultaneous requirement of increased production of pig and poultry products, the gallonage of milk sold off farms for all purposes, according to the official figures, increased only about $7 \%$ between 1939 and 1945 , and it is doubtful whether much of the $7 \%$ represents a true increase in production. It is rather a diversion to the milk market, owing to high prices offered, of milk previously used on the farm for other purposes. In fact, there is little doubt that, though numbers of cows have risen a little, milk yields/cow have tended to decline, and milk quality in winter, when the strain on the supply of concentrates or semi-concentrates is highest (and when, incidentally, human requirements for good nutritional quality in milk are highest), has tended to fall. There is no doubt that in recent years large numbers of our cows have been underfed in winter and have, therefore, not produced the full volume or quality of milk which they could have produced on an adequate diet.

I think the majority of experienced dairy farmers and livestock advisers would agree that without any change in the present size of our national dairy herd-which, for England and Wales, is some 3,400,000 cows and heifers in milk or in calf--a reasonable increase in the amount of concentrates or semi-concentrates fed to cows just before calving and during lactation would, in itself, give a marked increase, which can be conservatively estimated at probably $7-8 \%$, at least, in total milk output. Another $2-3 \%$, making $10 \%$ in all, could be added by increased efficiency in the cowshed, in milking technique (e.g. the more intelligent use of milking machines) and general 'cowmanship', the increase in yield entailing, of course, an increase in feeding-stuffs of almost the same magnitude.

A very serious difficulty, in view of the nature of the current programme of agricultural expansion, is that a large proportion of any increased imported concentrates would doubtless be fed to pigs and poultry. In fact, if we do import a relatively small extra quantity of feeding-stuffs, and if at the same time there is real pressure for increased home production of eggs and bacon, then the national milk output may not rise but fall.

To bring about, therefore, a quick increase in home milk-production, the immediate need is to provide forthwith adequate feeding-stuffs of the right quality for the existing bovine population. It is possible to estimate, to within a reasonable margin of error, the approximate annual requirements of additional concentrates needed to meet the Ministry's $1955^{-2}$ milk target-it is of the order of 390,000 t., perhaps $6 \%$ of our total pre-war import. Of this, about one-third should be high in protein (e.g. defatted decorticated ground-nut). To meet Dr Magee's larger requirement for liquid milk, we shall need not only an increase of some 590,000 t.* of concentrated feeding-stuffs, but also either an increase in numbers of cows, which for various reasons is undesirable, or a rise in yield/cow that can only come about by genetic improvement.

We have been, in fact, half-promised that 'considerably increased quantities of

* 520,000 t. would suffice if it were of the average pre-war quality as regards its content of 'digestible energy'. The feeding value (starch equivalent)/t. of concentrates now available has gone down by $12-15 \%$ since 1939 . 
feeding-stuffs should be available from abroad by 1949'. Be that as it may-and we have, since V.E. day, learnt caution, if not dubiety, regarding the prospects of increased imports of any kind-it seems certain that without a substantial improvement in the quantity and quality of home-produced feeding-stuffs we cannot hope to obtain the $15 \%$ rise in milk yields which the national expansion programme calls for during the next 4 or 5 years. Such improvement is, in my opinion, well within the bounds of possibility, and the foundation of it, at least over a very large part of the main dairying area of the United Kingdom, must be the short ley and greatly improved grassland management generally, though the possibilities of increasing home-produced fodders such as kale and kale silage, linseed, and even, in the southern part of England, maize silage, are far from negligible. Most agriculturists agree that the progress made during the war and since is small compared with what is possible. With the right strains of seeds, an adequate supply of fertilizers - -a dairy herd takes a very appreciable quantity of minerals and of nitrogen off the land-and some increased machinery and replacements, the production of semi-concentrates from a large proportion-probably three-quarters - of our grassland could, in a year of average weather, be increased by at least $50 \%$. Without any new findings, the application of existing knowledge would permit of richer grazing, extension of the grazing season in an average year by, perhaps, a fortnight at each end, better-quality hay, more and better-quality grass- (and other) silage, and these without diminution in the arable area. It is doubtful whether any great increase can be counted on in artificially dried grass, unless substantial supplies both of fuel and of the drying.plants, which need a good deal of steel in their manufacture, become available. It must not be forgotten that any increased supply of home-produced nitrogenous fertilizers also requires more coal.

I cannot do more than merely mention other important requirements on the dairy farm, all of which have a larger or smaller bearing on milk production, and most of which are at present missing on so many of our commercial farms, such as adequate and convenient cow houses (or milking bails), electric light and power, piped water supplies, skilled labour, adequate housing for that labour, up-to-date machinery, veterinary services. But even if all these were adequately provided, the supply of feeding-stuffs for the cow would be the limiting factor.

The average yield/cow in England and Wales at present is about 500 gal./year, which good feeding and management might raise to, perhaps, 550-560 gal. Given the feedingstuffs sufficient to bring up the yield/cow to the animal's present potentialities, what can be done to raise those potentialities?

The real answer, developed under wartime difficulties at Shinfield and Cambridge from the experimental to the practical stage, is large-scale artificial insemination from bulls of high quality. Now, from twenty centres and seventeen sub-centres, distributed over the greater part of England and Wales, this method is already being more and more widely used. With the vigorous support of the Milk Marketing Board, more centres are to be opened in the near future. In the year $195^{\circ}$, i.e. in 3 years, at present rates of progress it seems likely that at least a quarter of a million cows will be artificially inseminated, and this annual number will probably rise at an increasing rate for several years subsequently (Table 2). If the quality of bulls used in these centres can 
be maintained, the daughter of an artificially inseminated cow should, on the average, be capable of giving some 200 gal./year more than her dam. We can make a rough extrapolation from present trends-that in 6 years artificial insemination will be adding yearly to the milk supply a potential $50,000,000 \mathrm{gal}$.-i.e. a potential $3 \%$ rise in production, and that subsequently potential milk production will increase, as a result of artificial insemination, by not less than $\mathrm{I} \cdot 5 \%$ each year. How far this potential will

Table 2. A tentative estimate of the effects of artificial insemination on national milk production (increased supply of feeding-stuffs assumed)

\begin{tabular}{|c|c|c|c|c|c|c|}
\hline & & & & Potent & $\begin{array}{l}1 \text { extra milk } \\
\text { summated }\end{array}$ & produced, \\
\hline Year & $\begin{array}{c}\text { Cows } \\
\text { successfully } \\
\text { inseminated }\end{array}$ & $\begin{array}{c}\text { Heifers produced } \\
\text { which reach } \\
\text { maturity* }\end{array}$ & $\begin{array}{l}\text { Year heifers } \\
\text { come into } \\
\text { milk }\end{array}$ & gal. $\times 10^{6}$ & $\begin{array}{c}\text { Percentage } \\
\text { of national } \\
\text { supply }\end{array}$ & $\begin{array}{l}\text { Percentage of } \\
\text { I } 945-6 \text { liquid } \\
\text { consumption } \\
\text { (if all extra } \\
\text { milk was } \\
\text { consumed } \\
\text { liquid) }\end{array}$ \\
\hline 1947 & $80,000 t$ & 28,000 & 1950 & $5 \cdot 6$ & 0.4 & 0.4 \\
\hline 1948 & 140,000 & 49,000 & $195 I$ & 15.4 & I. 0 & $\mathrm{r} \cdot \mathrm{r}$ \\
\hline I949 & 190,000 & 70,000 & 1952 & 29.4 & $x \cdot 8$ & $2 \cdot I$ \\
\hline I950 & 270,000 & 95,000 & 1953 & $48 \cdot 4$ & 3.0 & $3 \cdot 5$ \\
\hline $195 I$ & 360,000 & 126,000 & 1954 & $73 \cdot 6$ & $4 \cdot 6$ & $5 \cdot 3$ \\
\hline
\end{tabular}

be realized depends again on increased feeding-stuffs and improved farm management. Considerably more knowledge and skill are required to manage successfully a herd of 700 gal. cows than a herd of 500-galloners, both in cropping the same area for increased fodder and in improved livestock management and cowshed technique. The technical training both of the dairy farmer and his cowman must improve pari passu with the improvement in the milk-producing capacity of their livestock, or much of the benefit of artificial insemination will be lost.

\section{Cheese}

Unless milk which would otherwise be used for liquid consumption is withdrawn from the liquid market and turned, with some wastage of nutrients, into cheese, it seems unlikely that cheese production at home will exceed very greatly the present annual amount, equivalent to some $45,000,000$ gal. of milk. This amount is only sufficient to provide about $\frac{1}{3} \mathrm{oz}$. cheese/head/week, as against the estimated need of $3 \mathrm{oz}$./head and the present ration of about $2 \mathrm{oz}$. Most of the present ration comes from abroad, and it seems likely that most of our cheese needs, for a considerable time, will either have to be met from abroad, met at the expense of about one-third of our present liquid milk supply, or not met at all.

\section{Butter}

Almost the same applies to butter. Less than $30,000,000$ gal. of milk were made into butter in 1946 , providing less than $0.1 \mathrm{oz}$./head/week. This is a negligible fraction of even our present miserable ration of $2 \mathrm{oz}$./week. Much milk, nearly $0.5 \mathrm{pt}$./day, is 
needed to provide even $2 \mathrm{oz}$. butter/person/week. Almost all our butter is at present imported, as is, of course, almost all the fat needed for margarine manufacture. In this connexion, it is perhaps worth calling attention to the fact that if ground-nuts can be imported whole from the projected East African production areas and processed in this country, our fat supplies will benefit twice--by the extracted oil for margarine, and by the additional milk fat which will be produced in the improved yields of our cows, when they receive additional ground-nut cake in their production rations.

\section{SUMMARY}

I. The nutritionist's requirements call for an increase in milk production of some $25 \%$. This cannot be met unless there is a very substantial increase-of the order of $600,000 \mathrm{t}$. annually_-of concentrated feeding-stuffs for cows in milk. Much of this must come from abroad. Probably at least a $10 \%$ rise in milk output could be obtained, with our present size and genetic quality of cow population, by feeding more concentrates and by improved management on the farm.

2. An increase in the quality, rather than in the number, of dairy cows is also required. Artificial insemination from high-quality bulls, together with the more usual methods of herd improvement, should permit of the rest of the $25 \%$ increase being met over a period of years-perhaps 9 or ro years-without any important change in the number of cows. Additional feeding-stuffs will, of course, be needed, as the quality of the cows improves.

3. The need for improved farm methods and generally increased efficiency of management of land for fodder production and of the dairy herd for milk production will put an immediate strain on the National Agricultural Advisory Service and will entail organized technical training in modern methods for the majority of existing dairy farmers and cowmen, as well as for new entrants.

4. As regards other dairy products, the large demands for milk for consumption in the liquid form will virtually mean that most of the requirements for cheese and butter will have to be met from sources abroad. The volume of milk needed to provide the cheese and butter requirements is approximately equal to that now consumed liquid.

\section{REFERENCES}

Bransby, E. R., Magee, H. E., Bowley, M. C. \& Stanton, B. J. (1947). Brit. F. Nutrit. I, 275. Ministry of Agriculture and Fisheries ( 1947). F. Minist. Agric. 54, 244.

\section{Home Production of Meat}

\section{By J. Hammond, School of Agriculture, Cambridge}

\section{Needs}

The best basis on which to start a consideration of needs is probably that of the food requirements of man as published by the U.S.A. National Research Council (I94I). This recommends for a moderately active man a daily allowance of $3000 \mathrm{Cal}$., $70 \mathrm{~g}$. 